України професор кафедри кримінально-правових дисциплін Харківського національного університету імені В.Н. Каразіна (м. Харків, Україна)

Шайтуро О.П.

кандидат юридичних наук, старший викладач кафедри кримінально-правових дисциилін ХаркіВського національного університету імені В.Н. Каразіна (м. ХаркіВ, Украйна)

\title{
ПОНЯТТЯ ТА СИСТЕМА ПРАВООХОРОННИХ ОРГАНІВ (ОРГАНІВ ПРАВОПОРЯДКУ) У КОНТЕКСТІ НОВОГО ЗАКОНУ «ПРО НАЦОНАЛЬНУ БЕЗПЕКУ УКРАЇНИ»: ПИТАННЯ ПРАВОВОЇ ВИЗНАЧЕНОСТІ
}

У статті розглянуто проблематику формулювання поняття та визначення системи правоохоронних органів (органів правопорядку) у контексті нового Закону України «Про національну безпеку України». Проаналізовано співвідношення дефініцій «правоохоронні органи», «державні органи спеціального призначення 3 правоохоронними функціями», «правоохоронні органи спеціального призначення», «правоохоронні та розвідувальні органи», «сили безпеки і оборони». Здійснено наукову класифікацію правоохоронних органів, виокремлено сутнісні риси органів правопорядку.

Ключові слова: правоохоронні органи (органи правопорядку), система правоохоронних органів, правоохоронні органи спеціального призначення, державні органи з правоохоронними функціями.

Постановка проблеми. Передусім зазначимо, що в новому Законі України «Про національну безпеку України» від 21.06.2018 № 2469-VIII, який набрав чинності 08.07.2018 (далі - Закон) [1], отримали розвиток положення відразу трьох законів, які діяли перед тим: «Про основи національної безпеки», «Про організацію оборонного планування» $\mathrm{i}$ «Про демократичний цивільний контроль над Воєнною організацією і правоохоронними органами держави». Цей закон запроваджує також низку інновацій, зокрема й щодо створення комплексної системи правоохоронних органів держави як складової сил безпеки і оборони України.

Насамперед поряд 3 широко вживаним раніше терміном «правоохоронні органи», законодавець запровадив нові поняття: «державні органи спеціального призначення з правоохоронними функціями», «правоохоронні органи спеціального призначення», «правоохоронні та розвідувальні органи», «сили безпеки і оборони». У 2016 році на конституційному та законодавчому рівнях було закріплено термін «органи правопорядку» ( п. 2 ст. 131-1 Конституції України, ст. 61 Закону України «Про судоустрій і статус суддів»), що замінив термін «органи внутрішніх справ», який на сьогодні вже не вживаний. Отже, убачається важливим з'ясувати сутність цих нововведень, що переконливо свідчить про наукову обгрунтованість і практичну 
доцільність вироблення нового поняття та встановлення сучасної системи правоохоронних органів (органів правопорядку).

Аналіз останніх досліджень i публікацій. Зауважимо, що 3 проблематики визначення поняття «правоохоронні органи» $є$ чимало наукових і навчально-методичних праць (Р. М. Білоконь, І. В. Бондаренко, А. П. Гель, В. В. Долежан, С. О. Іваницький, І. М. Козьяков, В. Т. Маляренко, М. І. Мельник, В. В. Сухонос, В. Р. Остропілєць, Н. В. Топчій та ін.), у яких проте не надано чіткої відповіді на основне конщептуальне питання - що таке правоохоронні органи, у чому полягають особливості їх статусу та функцій, а відтак, які державні органи належать до складу правоохоронних? Окрім цього, більшість досліджень проведено до конституційних змін 2016 року (щодо правосуддя), реформування правоохоронної системи. На сьогодні змінилася правоохоронна політика держави, що дає підстави для нового аналізу проблематики визначення поняття та системи правоохоронних органів (органів правопорядку). Це свідчить про актуальність обраної тематики дослідження та своєчасного їі аналізу.

Формування цілей. Метою статті є зіставлення та дослідження норми чинного законодавства, що регламентує основи організації та діяльності правоохоронних органів (органів правопорядку), що дасть змогу порівняти спільне та відмінне, а також сформувати на цій основі науково-обгрунтовані пропозиції та висновки.

Виклад основного матеріалу. Аналіз чинного законодавства показує, що законодавець тлумачить правоохоронні органи через надання їх конкретного переліку (органи прокуратури, Національної поліції, служби безпеки, Військової служби правопорядку в Збройних силах України, Національне антикорупційне бюро України, органи охорони державного кордону, органи доходів і зборів, органи і установи виконання покарань, органи державного фінансового контролю тощо (ст. 2 чинного Закону України «Про державний захист працівників суду i правоохоронних органів» від 23.12.1993). Цей перелік постійно розширюється через унесення до нього нових державних органів, які здійснюють правозастосовні або правоохоронні функції (наприклад, Служба судової охорони).

Унаслідок виокремлення в системі правоохоронних органів такого специфічного напряму, як проведення слідства (назву законодавець постійно уточнює, остання - досудове розслідування), поняття правоохоронних органів поширили на прокуратуру й нові органи слідства (слідчі органи). Зокрема, йдеться про Національне антикорупційне бюро України, Державне бюро розслідувань, слідчі органи Державної кримінально-виконавчої служби України (24.04.2018 Конституційний Суд України визнав не конституційними положення ч. 6 ст. 216 Кримінального процесуального кодексу України (далі - КПК) щодо слідчих підрозділів цієї служби), що лише утруднило розуміння цього терміна та особливостей правового статусу правоохоронних органів.

Зазначимо й те, що в науковому обігу широко використовується термін «органи кримінальної юстиції». Податкове та митне законодавство кодифікує термін «контролюючі органи», під якими розуміють державні 
податкові інспекції та органи митного спрямування Державної фіскальної служби України. (Ця служба відповідно до постанови Кабінету Міністрів України від 18.12.2018 № 1200 знову реорганізована в Державну податкову службу України та Державну митну службу України (органів доходів і зборів)).

Також продовжує свою діяльність податкова міліція, на яку відповідно до Закону від 15.03.2018 № 2337-VIII поширюється дія Дисциплінарного статусу Національної поліції України.

3 огляду на таку термінологічну невизначеність, на нашу думку, у дальшому на законодавчому рівні доцільне збереження лише двох понять: «правоохоронні органи» та «органи правопорядку» (які здійснюють негласні слідчі (розшукові) дії). Ці поняття співвідносяться як родове та видове, про що автори статті вже зазначали раніше [2]. Тобто поняття «правоохоронні органи» має використовуватися як узагальнювальне поняття й здійснення поділу цієї системи органів залежно від їх конкретних функцій та призначення в механізмі права. Це означатиме, що будь-який орган правопорядку є й правоохоронним органом, але не всі правоохоронні органи є органом правопорядку. Навіть більше, не всі органи правопорядку (які здійснюють оперативно-розшукову діяльність, точніше підрозділи цих органів), що вказані в ст. 5 Закону України «Про оперативно-розшукову діяльність» від 18.02.1992 № 2135-XII (зі змінами) є органом, який проводить негласні слідчі (розшукові) дії. Адже ч. 6 ст. 246 КПК України містить вичерпний (закритий) перелік уповноважених на те оперативних підрозділів.

До прикладу, Державна лісова охорона згідно з ч .1 ст. 2 Закону України «Про державний захист працівників суду і правоохоронних органів», а також зі ст. 89 Лісового кодексу України має статус правоохоронного органу, проте вона не є органом правопорядку. Теж стосується й органів державного фінансового контролю, рибоохорони тощо. Своєю чергою, Управління державної охорони України, виходячи зі ст. 5 Закону України «Про оперативно-розшукову діяльність» має ознаки органу правопорядку, проте їх відповідний підрозділ не має права на проведення негласних слідчих (розшукових) дій. Теж саме стосується й розвідувальних органів відповідних міністерств і відомств.

Таке твердження кореспондує з положеннями Конституції України, у якій також проведено відмінність між «правоохоронними органами» загалом (ч. 3 ст. 17) та, скажімо, «уповноваженими Законом органами», які в разі нагальної необхідності запобігти злочину чи його припиненню можуть «застосувати тримання особи під вартою як тимчасовий запобіжний захід» (ч. 2 ст. 29). По суті, йдеться про відповідні органи правопорядку.

3 огляду на це органи правопорядку мають право легального застосування примусу, що зумовлюе особливості цього інституту, висуваючи до їхніх працівників особливі вимоги щодо фахової підготовки, психологічних і моральних якостей тощо. Крім того, характерним для органів правопорядку є те, що вони мають у своєму складі озброєні формування. Це є винятковою ознакою для цих органів, що виділяє їх в окрему групу, до якої належать уповноважені оперативні підрозділи: 
- Національної поліції;

- органів безпеки;

- Національного антикорупційного бюро України;

- Державного бюро розслідувань;

- органів, що здійснюють контроль за додержанням податкового і митного законодавства;

- органів Державної кримінально-виконавчої служби України;

- органів Державної прикордонної служби України (ч. 6 ст. 246 КПК України).

На наш погляд, беручи до уваги викладене, а також приписи статей 18-21 аналізованого Закону сучасна система правоохоронних органів (органів правопорядку) має мати такі чотири складові: 1) правоохоронні органи загального призначення (Національна поліція України, Державне бюро розслідувань, Державна служба України з надзвичайних ситуацій, Державна міграційна служба України); 2) правоохоронні органи спеціального призначення (Державна прикордонна служба України, Національне антикорупційне бюро України, Державна кримінальновиконавча служба України, податкова міліція); 3) державні органи спеціального призначення 3 правоохоронними функціями (Служба безпеки України, Управління державної охорони України, Національна гвардія України); 4) інші правоохоронні органи (Державна лісова охорона, органи фінансового контролю, рибоохорони тощо).

Зокрема, Національна поліція України як складова Міністерства внутрішніх справ України (далі - МВС) має стати правоохоронним органом загального призначення в державі, який діє як центральний орган виконавчої влади, що забезпечує громадську безпеку і порядок, охорону прав і свобод людини, інтересів суспільства і держави, протидію злочинності, а також надає визначені законом послуги з допомоги особам, які з особистих економічних, соціальних причин або внаслідок надзвичайних ситуацій потребують такої допомоги (ч. 4 ст. 18 Закону, ст. 1 Закону України «Про Національну поліцію»).

Такий статус має набути й Державне бюро розслідувань як центральний орган виконавчої влади, що здійснює правоохоронну діяльність для запобігання виявлення, припинення, розкриття та розслідування злочинів, віднесених до його компетенції (ст. 1 Закону України «Про Державне бюро розслідувань»). Законодавець цілеспрямовано підкреслює, що ці органи є центральним органом виконавчої влади, їх діяльність грунтується на принципах верховенства права, забезпечення дотримання прав i свобод людини i громадянина, безперервності, законності, забезпечення єдності державної політики, відкритості та прозорості, відповідальності.

Як центральний орган виконавчої влади (у складі МВС) діє також Державна служба з надзвичайних ситуацій, яка реалізує державну політику у сферах цивільного захисту, захисту населення і територій від надзвичайних ситуацій, запобігання їх виникненню, ліквідащії наслідків надзвичайних ситуащій, проведення аварійно-рятувальних робіт, пожежогасіння, пожежної та техногенної 
безпеки, роботи рятувальних служб під час аварій, а також гідрометеорологічної діяльності (ч. 7 ст. 18 Закону).

Державна міграційна служба України як складова МВС реалізує державну політику у сферах міграції (імміграції), серед іншого, протидії нелегальній (незаконній) міграції, громадянства, реєстрації фізичних осіб, зокрема біженців та інших визначених законодавством категорій мігрантів (ч. 8 ст. 18 Закону). Ця служба також має статус центрального органу виконавчої влади.

Державна прикордонна служба України (далі - ДПСу) є правоохоронним органом спеціального призначення, що реалізує державну політику у сфері безпеки державного кордону України та охорони суверенних прав України в тї виключній (морській) економічній зоні (ч. 6 ст. 18 Закону, ст. 1 Закону України «Про державну прикордонну службу України»). До того ж ДПСУ є також складовою МВС.

Державним правоохоронним органом спеціального призначення є по суті Національне антикорупційне бюро України, на яке покладено попередження, виявлення, припинення, розслідування корупційних правопорушень, віднесених до його підслідності, а також запобігання вчиненню нових. Завданням Національного бюро є протидія кримінальним корупційним правопорушенням, що скоюють вищі посадові особи, уповноважені на виконання функцій держави або місцевого самоврядування, та становлять загрозу національній безпеці (ст. 1 Закону України «Про Національне антикорупційне бюро Украӥни»).

Державна кримінально-виконавча служба України (органи і установи виконання покарань) також має стати правоохоронним органом спеціального призначення, якій визначено завдання щодо здійснення єдиної державної політики у сфері виконання кримінальних покарань (ст. 1 Закону України «Про Державну кримінально-виконавчу службу України»).

До складу групи правоохоронних органів (органів правопорядку) слід також зарахувати податкову міліцію, яка 1998 року, з відповідними змінами в законодавстві, була наділена слідчими та оперативно-розшуковими функціями в податковій сфері (на сьогодні - органи, що здійснюють контроль за додержанням податкового та митного законодавства). 3 огляду на останній законопроект вона найближчим часом має бути реорганізована в Національне бюро фінансових розслідувань. Безсумнівно, попереду жвава дискусія щодо дальшої роботи фінансових детективів.

Принципову позицію 3 реформування правоохоронної системи застосовано до повноважень Служби безпеки України (далі - СБУ). Згідно $з$ оновленою редакцією ст. 1 Закону України «Про Службу безпеки України», а також частини 1 ст. 19 цього Закону є державним органом спеціального призначення з правоохоронними функціями, що забезпечують державну безпеку, неухильно здійснюючи дотримання прав і свобод людини i громадянина:

1) протидію розвідувально-підривній діяльності проти України;

2) боротьбу з тероризмом;

3) контррозвідувальний захист державного суверенітету, конституційного ладу й територіальної цілісності, оборонного і науково-технічного потенціалу, 
кібербезпеки, економічної та інформаційної безпеки держави, об'єктів критичної інфраструктури;

4) охорону державної таємниці.

Тобто, у новому законодавстві переглянуто функціональні напрями діяльності СБУ. 3 одного боку, їй надано додаткові повноваження, а з іншого - за ії діяльністю має бути посилено цивільний, зокрема й парламентський контроль. Отже, на сьогодні вона має займатися тільки питаннями щодо захисту державної таємниці, контррозвідкою та запобіганням тероризму, а не боротьбою 3 економічними злочинами, що $\epsilon$ предметом відання Департаменту захисту економіки Національної поліції.

Національна гвардія України є військовим формуванням 3 правоохоронними функціями, призначеними для виконання завдань із захисту та охорони життя, прав, свобод і законних інтересів громадян, суспільства і держави від злочинних та інших протиправних посягань, охорони громадського порядку та забезпечення громадської безпеки, а також у взаємодії з іншими органами - із забезпечення державної безпеки і захисту державного кордону України, припинення терористичної діяльності, діяльності незаконних воєнізованих або збройних формувань, організованих злочинних груп та організацій. У мирний час Національна гвардія України входить до складу сил безпеки і виконує правоохоронні функції, а також розвиває спроможності необхідні для виконання завдань у складі сил оборони (ч. 5 ст. 18 Закону, ст. 1 Закону України «Про Національну гвардію України»).

3 окремими правоохоронними функщіями діє на сьогодні також Управління державної охорони України, яке відповідно до ст. 21 Закону здійснює державну охорону органів державної влади України, забезпечує безпеку посадових осіб та охорону об'єктів, визначених законом (ст. 1 Закону України «Про державну охорону органів державної влади та посадових осіб»).

Розвідувальні органи як суб'єкти забезпечення національної безпеки і оборони України беруть участь у формуванні й реалізації державної політики 3 питань національної безпеки і оборони у визначених законодавством сферах, тому вони не мають статусу правоохоронного органу (ст. 20 Закону). Розвідувальні органи України - це державні органи або структурні підрозділи в їх складі, уповноважені законами «Про розвідувальні органи України», «Про Службу зовнішньої розвідки України» здійснювати розвідувальну діяльність для захисту національних інтересів України від зовнішніх загроз.

На противагу попереднього Закону України «Про основи національної безпеки» 2003 року новий Закон не передбачає як самостійного суб'єкта національної безпеки України (правоохоронного органу) прокуратуру. Зауважимо, що така позиція законодавця є цілком обгрунтованою. Адже за конституційними змінами 2016 року (щодо правосуддя) прокуратура України є суміжним (автономним) правовим інститутом судової влади (правосуддя) (ст. 131-1 Конституції України). Навіть більше, пунктом 2 цієї статті на прокуратуру покладається функція нагляду за негласними та 
іншими слідчими й розшуковими діями органів правопорядку, тобто тільки органів виконавчої влади [3, с. 209-210].

Висновки. Отже, проаналізувавши чинне законодавство, констатуємо, що правоохоронні органи (органи правопорядку) в сучасному розумінні - це винятково органи виконавчої влади, яким, згідно із законодавством надано статус і повноваження державного правоохоронного органу для захисту важливих для суспільства й особи інтересів, прав і свобод людини і громадянина, забезпечення якого є пріоритетним завданням їх діяльності.

Беручи до уваги наведене, доцільно ініціювати розробку законопроекту про систему правоохоронних органів України (органів правопорядку), у якому встановити їх перелік або визначити вичерпні та конкретні критерії віднесення державних або інших органів (можливо адвокатури України) до складу правоохоронних, що вбачається більш правильним 3 огляду на динаміку розвитку правоохоронної системи й необхідність ї̈ постійної модернізації та вдосконалення.

Одним із критеріїв віднесення правоохоронних органів до органів правопорядку, безумовно є наявність повноважень щодо провадження досудового розслідування кримінальних правопорушень та здійснення оперативно-розшукової діяльності, оскільки саме їх реалізація спрямована на захист громадян і держави від неправомірних посягань, поновлення порушених прав та інтересів, тобто на застосування й охорону права, регламентованого Конституцією та законами України.

\section{Використані джерела:}

1. Про національну безпеку України : Закон України від 21 червня 2018 року № 2469-VIII. Відомості Верховної Ради України. 2018. № 31. Ст. 241.

2. Руденко М. В., Шайтуро О. П. Щодо визначення поняття «органи правопорядку». Вісник ХНУ ім. В.Н. Каразіна. Серія «Право». 2017. № 23. С. 158-160.

3. Судові та правоохоронні органи України: підруч. для студ. юрид. вищ. навч. закл. / за ред. М. В. Руденка. Харків: ХНУ ім. В.Н. Каразіна, 2018. 362 с.

\section{Стаття надіӥшла до редколегї 30.01.2019}

Руденко Н. В., доктор юридических наук, профессор, заслуженный юрист Украины, профессор кафедры уголовно-правовых дисциплин Харьковского национального университета имени В. Н. Каразина (г. Харьков, Украина)

Шайтуро О. П., кандидат юридических наук, старший преподаватель кафедры уголовно-правовых дисциплин Харьковского национального университета имени В. Н. Каразина (г. Харьков, Украина)

Понятие и система правоохранительных органов (органов правопорядка) в контексте нового Закона Украины «О национальной безопасности Украины»: вопросы правовой определенности

В статье рассмотрена проблематика определения понятия и становления системы правоохранительных органов (органов правопорядка) в контексте нового Закона Украины «О национальной безопасности Украины». Проанализировано соотношение дефиниций «правоохранительные органы», «государственные органы специального назначения с правоохранительными функциями», «правоохранительные органы специального назначения», 
«правоохранительные и разведывательные органы», «силы безопасности и обороны». Осуществлена научная классификация правоохранительных органов, выделены сущностные черты органов правопорядка.

Ключевые слова: правоохранительные органы (органы правопорядка), система правоохранительных органов, правоохранительные органы специального предназначения, государственные органы с правоохранительными функциями.

Rudenko M., Shaituro O. The Concept and the System of Law Enforcement Bodies (the Bodies of Legal Order) in the Context of the New Law of Ukraine "On National Security of Ukraine": Issues of Legal Definiteness

The problems of definition of the concept and formation of the system of law enforcement agencies (law enforcement agencies) in the context of the new Law of Ukraine "On National Security of Ukraine" are considered.

So, after analyzing the current legislation, one can state that law enforcement bodies (law enforcement agencies) in the modern sense are exclusively executive authorities, which, according to the legislation, are given the status and powers of a state law enforcement agency to protect the interests, rights and freedoms important to society and individuals. and a citizen whose provision is a priority task of their activities.

Taking into account the above, it is advisable to initiate the development of a draft law on the system of law enforcement agencies of Ukraine (law enforcement) in which to establish their list or to define exhaustive and specific criteria for assigning state or other bodies (possibly Ukrainian lawyers) to law enforcement, which seems more correct in view of the dynamics of development the law enforcement system and the need for its constant modernization and improvement.

One of the criteria for assigning law enforcement to law enforcement agencies is, of course, the existence of powers to conduct a pre-trial investigation of criminal offenses and to carry out operative and investigative activities, since it is their realization aimed at protecting citizens and the state from unlawful encroachments, restoration of violated rights and interests, that is, on application and protection of the right regulated by the Constitution and laws of Ukraine.

Key words: law enforcement agencies, law enforcement system, law enforcement agencies of special purpose, state authorities with law enforcement functions. 